\title{
Flavonoids and fatty acids of Camellia japonica leaves extract
}

\section{Cinthia M. Azuma, ${ }^{1}$ Flávia Cristina S. dos Santos, ${ }^{1}$ João Henrique G. Lago $^{2}$}

${ }^{I}$ Centro de Ciências Biológicas e da Saúde, Universidade Presbiteriana Mackenzie, São Paulo, Brazil,

${ }^{2}$ Departamento de Ciências Exatas e da Terra, Universidade Federal de São Paulo, Diadema, Brazil.

\begin{abstract}
The ethanol extract from the leaves of Camellia japonica L., Theaceae, showed antiradical potential in the DPPH test using TLC plates $\left(\mathrm{SiO}_{2}\right)$. Aiming the isolation of active compounds, this extract was partitioned between $\mathrm{BuOH}: \mathrm{H}_{2} \mathrm{O}$ $(1: 1)$ and the two obtained phases were also evaluated to detection of antiradical activity. The active $\mathrm{BuOH}$ phase was fractionated in Sephadex LH-20 and silica (normal or reverse phase) to afford three aglycone flavonoids (quercetin, kaempferol and apigenin), which have been described in the $C$. japonica at first time, two glycosilated flavonoids (rutin and quercetrin), and a mixture of saturated fatty acids. The structures of isolated compounds were defined by NMR and GC/MS analyses.
\end{abstract}

Revista Brasileira de Farmacognosia Brazilian Journal of Pharmacognosy 21(6): 1159-1162, Nov./Dec. 2011

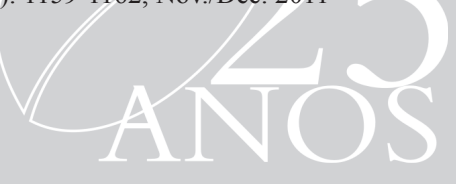

\section{Short Communication}

Received 20 Oct 2010

Accepted 1 Mar 2011

Available online 29 Jul 2011

Keywords:

antiradical potential

Camellia japonica

fatty acids

flavonoids

ISSN 0102-695X

http://dx.doi.org/10.1590/S0102$695 \times 2011005000128$

\section{Introduction}

Camellia japonica L., Theaceae, is a tree belonging to Theaceae family and has been used in folk medicine in Japan, China, and Korea to the treatment of stomachic illness and as anti-inflammatory (Yoshikawa et al., 1996). Chemically, this species showed to be constituted by triterpenes (Itokawa et al., 1981; Akihisa et al., 1997; Thao et al., 2010), saponins (Yoshikawa et al., 1996; Ito et al., 1967; Itokawa et al., 1969; Yoshikawa et al., 1994), glycosylated flavonoids (Onodera et al., 2006), and tannins (Hatano et al., 1991; Han et al., 1994; Hatano et al., 1995a; Hatano et al., 1995b; Yoshida et al., 1989; Park et al., 2002). Several of these derivatives showed biological activity including antioxidant (Onodera et al., 2006), antifungal (Nagata et al., 1985), inhibitory effect on human immunodeficiency virus-1 protease (Hatano et al., 1991; Han et al., 1994; Hatano et al., 1995; Yoshida et al., 1989; Park et al., 2002), and cytotoxic potential (Thao et al., 2010).

As part of our ongoing effort to isolate antiradical compounds from vegetal species using TLC/DPPH assay (Ceruks et al., 2007), in this paper we describe the isolation of three free (quercetin, apinenin, and kampferol) and two glycosilated (rutin and quercetrin) flavonoids from $\mathrm{BuOH}$ phase from EtOH extract of C. japonica leaves. Furthermore, a mixture composed by fatty acids was identified by GC/ MS after methylation procedure.

\section{Material and Methods}

\section{General experimental procedures}

${ }^{1} \mathrm{H}$ NMR spectra were recorded at 200 and 300 $\mathrm{MHz}$ and ${ }^{13} \mathrm{C} \mathrm{NMR}$ at 50 and $75 \mathrm{MHz}$ on Bruker AC200 and DPX-300 spectrometers, respectively. $\mathrm{CDCl}_{3}$,

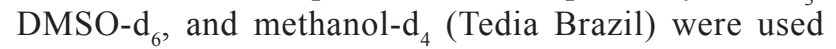
as solvent and as internal standard. Chemical shifts are reported in $\delta$ units (ppm) and coupling constants $(J)$ in Hz. GC/LREIMS were measured in a Shimadzu GC-17A chromatograph interfaced with a MS-QP-5050A mass spectrometer. Temperature programming was performed from $150-300{ }^{\circ} \mathrm{C}$ at $15{ }^{\circ} \mathrm{C} / \mathrm{min}$, then isothermal at 300 ${ }^{\circ} \mathrm{C}$ for $5 \mathrm{~min}$. The injector and detector temperatures were 150 and $320{ }^{\circ} \mathrm{C}$, respectively, and helium was used as the carrier gas. Sephadex LH-20 (Amersham Biosciences) was used for column chromatographic separation. Silica gel 60 PF254 (Merck) was used for analytical TLC $(0.25 \mathrm{~mm})$ and reverse-phase silica gel (RP18 F254 S, Merck) was used for preparative TLC $(1.0 \mathrm{~mm})$.

\section{Plant material}


Camellia japonica L., Theaceae, leaves were collected in March, 2006 in São Paulo/SP, Brazil. The plant was identified by Dr. Oriana A. Fávero by comparison with a voucher specimen deposited at the Herbarium of Instituto de Botânica de São Paulo, São Paulo, SP, Brazil.

\section{Extraction and isolation of the constituents}

Dried and powdered leaves of $C$. japonica (252 g) were deffated n-hexane (three times at room temperature) and then exhaustively extracted by maceration with EtOH at room temperature. Evaporation of the solvent under reduced pressure afforded the crude ethanol extract $(4.7 \mathrm{~g})$, which was partitioned between $\mathrm{BuOH}: \mathrm{H}_{2} \mathrm{O}(1: 1)$. The organic phase, after dried over anhydrous $\mathrm{Na}_{2} \mathrm{SO}_{4}$, was concentrated under reduced pressure yielding $3.4 \mathrm{~g}$ of a residue. Part of this material (2.9 g) was purified using Sephadex LH20 column chromatography and eluted with $\mathrm{MeOH}$ to afford 71 fractions $(50 \mathrm{~mL})$ which were pooled together in seven groups after TLC analysis. Group 2 (690 mg) was subjected to Sephadex LH-20 column chromatography and eluted with $\mathrm{CHCl}_{3}: \mathrm{MeOH}(1: 1)$ to afford thirteen fractions $(10 \mathrm{~mL}$ each). After TLC analysis, these fractions were combined into three subgroups (I-III). Sub-group II (35 mg) was composed by pure 4 while sub-group III (42 mg) by pure 5. Group 4 (65 mg) was purified by reverse phase preparative TLC (MeOH: $\mathrm{H}_{2} \mathrm{O} 1: 1$ ) to afford $36 \mathrm{mg}$ of a mixture of fatty acids and $14 \mathrm{mg}$ of $\mathbf{1}$. Fraction $6(40 \mathrm{mg})$ was purified by reverse phase preparative TLC $\left(\mathrm{MeOH}: \mathrm{H}_{2} \mathrm{O} 1: 1\right)$ to afford pure 3 (4 $\mathrm{mg}$ ) and $\mathbf{2}$ (9 $\mathrm{mg}$ ).

\section{Methylation procedure}

The $36 \mathrm{mg}$ of free fatty acids were accurately weighed into a $50 \mathrm{~mL}$ flask and dissolved in $5 \mathrm{~mL}$ of $\mathrm{MeOH}$. After addition of $5 \mathrm{~mL}$ of $\mathrm{HCl}(1.5 \mathrm{~mol} / \mathrm{L})$, the solution was refluxed during $2 \mathrm{~h}$, extracted with $2 \times 20$ $\mathrm{mL}$ of EtOAc and successively with $\mathrm{H}_{2} \mathrm{O}$ until $\mathrm{pH} 7$. The organic phase was dried over anhydrous $\mathrm{Na}_{2} \mathrm{SO}_{4}$ and after evaporation of solvent was obtained $28 \mathrm{mg}$ of methylated derivatives, which were immediately analyzed by GC/LREIMS.

\section{Assay to detection of antiradical potential}

Compounds 1-5 $(1.0 \mathrm{mg} / \mathrm{mL}$ in methanol) were applied to TLC plates, eluted with appropriate solvent systems and sprayed with a solution $2.0 \mathrm{mg} / \mathrm{mL}$ of DPPH in methanol. After evaporation of the solvent (about $5 \mathrm{~min}$ ), the antiradical potential, comparatively with positive control $\alpha$-tocopherol $(1.0 \mathrm{mg} / \mathrm{mL}$ in $\mathrm{CHCl}_{3}$ ), was observed by the appearance of yellow spots on violet background, according to that described in the literature (Ceruks et al., 2007).

\section{Results and Discussion}

Fractionation of the $\mathrm{BuOH}$ phase from $\mathrm{EtOH}$ extract of the leaves Camellia japonica L., Theaceae, yielded the isolation of five flavonoids (1-5) whose structures were identified based the analysis of data obtained from NMR spectra. Additionally, was obtained a mixture composed by saturated fatty acids which was characterized by GC/LREIMS analysis after methylation procedure.

The ${ }^{1} \mathrm{H}$ NMR spectra of compounds $\mathbf{1 - 5}$ showed the signals of H-6 and H-8 of flavonoids due the doublets at range $\delta 6.1-6.4(J \sim 2.0 \mathrm{~Hz})$ and at 6.2-6.4 $(J \sim 2.0 \mathrm{~Hz})$, indicating a same substitution profile to ring A. Similarly, the three peaks at 7.2-7.6 (d, $\left.J \sim 2.0 \mathrm{~Hz}, \mathrm{H}-2^{\prime}\right), 6.8\left(\mathrm{~d}, J \sim 8.5 \mathrm{~Hz}, \mathrm{H}-5^{\prime}\right)$ and 7.2-7.5 (dd, $J \sim 8.5$ and $\left.2.0 \mathrm{~Hz}, \mathrm{H}-6^{\prime}\right)$, observed in the spectra of compounds $\mathbf{1}, \mathbf{4}$, and $\mathbf{5}$, were indicative of 1,3,4-trissubtituted aromatic ring $\mathrm{B}$. The spectra of compounds 2 and 3 showed doublets at $\delta 6.9(J=8.5$ $\mathrm{Hz}, 2 \mathrm{H})$ and 7.7-8.0 $(J=8.5 \mathrm{~Hz}, 2 \mathrm{H})$, assigned to hydrogens $\mathrm{H}-3$ ' and $\mathrm{H}-2^{\prime}$, respectively, from aromatic ring $\mathrm{B}$. Based in the above evidences, associated to the presence of additional signal at $\delta 6.43(\mathrm{~s}, \mathrm{H}-3)$ to compound 2, the structures of free flavonoids were defined as quercetin (1), apigenin (2) and kaempferol (3), whose occurrence has been described at first time to $C$. japonica. Comparison of the ${ }^{13} \mathrm{C} \mathrm{NMR}$ data of these compounds with those reported in the literature (Agrawal, 1989), confirmed the structural proposition. ${ }^{1} \mathrm{H}$ NMR spectra of $\mathbf{4}$ and $\mathbf{5}$ showed similar signals of those observed to 1 besides of additional peaks at $\delta 5.30$ $(\mathrm{d}, J=7.0 \mathrm{~Hz}) / 4.40$ (br s) and at $\delta 5.23(\mathrm{~d}, J=1.0 \mathrm{~Hz}$ ), which could be assigned to annomeric hydrogens from rutinose and rhamnose units (Lee et al., 2004). Finally, after comparison of ${ }^{13} \mathrm{C}$ NMR data with those reported in the literature (Agrawal, 1989), the structures of these glycosylated flavonoids were defined as rutin (4) and quercetrin (5).<smiles>[R]c1cc(-c2oc3cc(O)cc(O)c3c(=O)c2[R])ccc1O</smiles>

$$
\begin{aligned}
& 1 \mathrm{R}_{1}=\mathrm{OH} ; \mathrm{R}_{2}=\mathrm{OH} \\
& 2 \mathrm{R}_{1}=\mathrm{R}_{2}=\mathrm{H} \\
& 3 \mathrm{R}_{1}=\mathrm{H} ; \mathrm{R}_{2}=\mathrm{OH} \\
& 4 \mathrm{R}_{1}=\mathrm{OH} ; \mathrm{R}_{2}=\text { OGlu-Rham } \\
& 5 \mathrm{R}_{1}=\mathrm{OH} ; \mathrm{R}_{2}=\text { ORham }
\end{aligned}
$$


The ${ }^{1} \mathrm{H}$ NMR spectrum to the mixture of fatty acids showed one deformed triplet at $\delta 0.89(\mathrm{t}, J=7.1$ $\mathrm{Hz}$ ), one intense singlet at $\delta 1.20$ and one triplet at $\delta 2.30(J=7.5 \mathrm{~Hz})$. The absence of signals between $\delta$ 4.5-6.0 indicated the occurrence of saturated chain (Moreira et al., 2007). Aiming the characterization of these derivatives, the fraction was methylated and than analyzed by GC/MS allowing the identification of six esters (methyl tridecanoate, methyl tetradecanoate, methyl pentadecanoate, methyl hexadecanoate, methyl heptadecanoate, and methyl octadecanoate), as showed in Table 1.

Table 1. Relative amount of methyl derivatives from fatty acids identified in the leaves of $C$. japonica.

\begin{tabular}{lc}
\hline \multicolumn{1}{c}{ Compound } & Relative amount $/ \%$ \\
\hline Methyl tridecanoate & 2.2 \\
Methyl tetradecanoate & 2.8 \\
Methyl pentadecanoate & 17.6 \\
Methyl hexadecanoate & 8.8 \\
Methyl heptadecanoate & 5.1 \\
Methyl octadecanoate & 37.0 \\
Total & 72.5 \\
\hline
\end{tabular}

All compounds isolated from the $\mathrm{BuOH}$ phase (1-5) were subjected to evaluation of antiradical potential by spraying a solution of $2.0 \mathrm{mg} / \mathrm{mL}$ of DPPH in methanol in a TLC plate $\left(\mathrm{SiO}_{2}\right)$. After 5 minutes, were observed strong yellow spots on violet background, suggesting that compounds 1-5 are responsible for antiradical potential observed in the crude extract/phases, as previously reported (Coutinho et al., 2010; Ceruks et al., 2007; Rosa et al., 2010).

\section{Acknowledgments}

We are grateful to $\mathrm{CNPq}$ for fellowships as well as to FAPESP for financial support.

\section{References}

Agrawal PK 1989. Carbon-13 NMR spectrum of flavonoids. Elsevier, New York, p 336.

Akihisa T, Yasukawa K, Kimura Y, Takase S, Yamanouchi S, Tamura T 1997. Triterpene alcohols from Camellia and Sasanqua oils and their anti-inflammatory effects. Chem Pharm Bull 45: 2016-2023.

Ceruks M, Romoff P, Fávero OA, Lago JHG 2007. Constituintes fenolicos polares de Schinus terebinthifolius Raddi (Anacardiaceae). Quim Nova 30: 597-599.

Coutinho ID, Kataoka VMG, Honda NK, Coelho RG, Vieira MC, Cardoso CAL 2010. Influência da variação sazonal nos teores de flavonóides e atividade antioxidante das folhas de Campomanesia adamantium (Cambess.) O. Berg, Myrtaceae. Rev Bras Farmacogn 20: 322-327.
Han L, Hatano T, Yoshida T, Okuda T 1994. Tannins of Theaceous plants. V. Camelliatannins F, G and H, three new tannins from Camellia japonica L. Chem Pharm Bull 42: 13991409.

Hatano T, Han L, Taniguchi S, Shingu T, Okuda T, Yoshida, T 1995a. Tannins and related polyphenols of Theaceous plants. VIII. Camelliatannins C and E, new complex tannins from Camellia japonica leaves. Chem Pharm Bull 43: 1629-1633.

Hatano T, Han L, Taniguchi S, Okuda T, Kiso Y, Tanaka T, Yoshida T 1995b. Camelliatannin D, a new inhibitor of bone resorption, from Camellia japonica. Chem Pharm Bull 43: 2033-2035.

Hatano T, Shida S, Han L, Okuda T 1991. Tannins of Theaceous plants. III. Camelliatannins A and B, two new complex tannins from Camellia japonica L.Chem Pharm Bull 39: 876-880.

Ito S, Kodama M, Konoike M 1967. Structure of camelliagenins. Tetrahedron Lett 8: 591-596.

Itokawa H, Nakajima H, Ikuta A, Iitaka Y 1981. Two triterpenes from the flowers of Camellia japonica. Phytochemistry 20: 2539-2542.

Itokawa H, Sawada N, Murakami T 1969. The structures of camelliagenin A, B and C obtained from Camellia Japonica L. Chem Pharm Bull 17: 474-480.

Lee JH, Ku CH, Baek N-I, Kim SH, Park HW, Kim DK 2004. Phytochemical constituents from Diodia teres. Arch Pharm Res 27: 40-43.

Moreira IC, Roque NF, Contini K, Lago JHG 2007. Sesquiterpenos e hidrocarbonetos dos frutos de Xylopia emarginata (Annonaceae). Rev Bras Farmacogn 17: 55-58.

Nagata T, Tsushida T, Hamaya E, Enoki N, Manabe S, Nishino C 1985. Camellidins, antifungal saponins isolated from Camellia japonica. Agr Biol Chem Tokyo 49: 11811186.

Onodera K, Hanashiro K, Yasumoto T 2006. Camellianoside, a Novel Antioxidant Glycoside from the Leaves of Camellia japonica. Biosci Biotech Biochem 70: 19951998.

Park JC, Hur JM, Park JG, Hatano T, Yoshida T, Miyashiro H, Min BS, Hattori M 2002. Inhibitory effects of Korean medicinal plants and camelliatannin $\mathrm{H}$ from Camellia japonica on human immunodeficiency virus type 1 protease. Phytother Res 16: 422-426.

Rosa EA, Silva BC, Silva FM, Tanaka CMA, Peralta RM, Oliveira CMA, Kato L, Ferreira HD, Silva CC 2010. Flavonóides e atividade antioxidante em Palicourea rigida Kunth, Rubiaceae. Rev Bras Farmacogn 20: 484-488.

Thao NTP, Hung TM, Lee MK, Kim JC, Min BS, Bae KH 2010. Triterpenoids from Camellia japonica and their cytotoxic activity. Chem Pharm Bull 58: 121-124.

Yoshida T, Chou T, Haba K, Okano Y, Shingu T, Miyamoto K, Koshiura R, Okuda T 1989. Camelliin B and nobotanin I, macrocyclic ellagitannin dimmers and related dimmers, and their antitumor activity. Chem Pharm Bull 37: 31743176.

Yoshikawa M, Harada E, Murakami T, Matsuda H, Yamahara J, Murakami N 1994. Camelliasaponins B1, B2, C1 and $\mathrm{C} 2$, new type inhibitors of ethanol absorption in rats from the seeds of Camellia japonica L. Chem Pharm Bull 42: 742-744, 
Yoshikawa M, Murakami T, Yoshizumi S, Murakami N, Yamahara J, Matsuda H 1996. Bioactive saponins and glycosides. V. Acylated polyhydroxyolean-12-ene triterpene oligoglycosides, camelliasaponins A1, A2, B1, $\mathrm{B} 2, \mathrm{C} 1$, and $\mathrm{C} 2$, from the seeds of Camellia japonica $\mathrm{L}$.: structures and inhibitory activity on alcohol absorption. Chem Pharm Bull 44: 1899-1907.

\section{*Correspondence}

João Henrique G. Lago

Departamento de Ciências Exatas e da Terra, Universidade Federal de São Paulo

09972-270, Diadema-SP, Brazil

joao.lago@unifesp.br

$\mathrm{Tel}+551155746513$ 